\title{
Yield parameters and stabilty of soybean [Glycine max. (L.) merril] as influenced by phosphorus fertilizer rates in two ultisols
}

\author{
Ikeogu U. N. and Nwofia G. E.* \\ Department of Agronomy, Michael Okpara University of Agriculture, Umudike, Abia State, Nigeria. \\ Accepted 6 February, 2013
}

\begin{abstract}
A field study was conducted for two years to assess the spatial and temporal effect of Phosphorus fertilizer on the yield, yield components and yield stability of five soybean genotypes in Umudike and Amakama in eastern Nigeria. The study was laid out as a split-plot in a randomized complete block with three replications. $\mathrm{P}$ rates of $0,10,20,30$ and $40 \mathrm{~kg} \mathrm{P} / \mathrm{ha}$ as triple superphosphate (TSP, 20\% P) was randomly allocated to sub-plots and five soybean varieties (TGX 1440-1E, TGX 1448-2E, TGX 1485-1D, TGX 1835-10E and TGX 1910-14F) to main plots. Phosphorus rate, year and location were considered as environmental factors in a genotype $x$ environment analysis. Genotype, $P$ rate, year, location and some interactions were significant for most of the traits studied. The Genotypes performed differently across the environments and a high positive and significant association existed between seed yield and number of pods per plant as well as the number of seeds per plant. Hence, these traits can be selected for in the improvement of soybean in this agro ecology. Genotype $x$ environment interactions (GEI) played a significant role in this study and should be given considerable attention in soybean breeding program for development of genetic materials adapted to a wide range of environments. TGX 1910-14F and TGX1440-1E were stable under different $P$ rates.
\end{abstract}

Key words: Soybean (Glycine max L.) genotypes, yield stability, grain yield, genotype $\mathrm{x}$ environment interaction (GEI).

\section{INTRODUCTION}

Soybean [Glycine max (L.) Merrill] is the world's leading source of oil and protein. It has the highest protein content of all food crops and is second only to groundnut in terms of oil content among food legumes (Fekadu et al., 2009; Alghamdi, 2004). The spread of soybean from its native land of origin has been mainly due to its adaptability and predominant use as a food crop for human nutrition, source of protein for animals, medicinal plant and lately as an industrial crop (Yusuf and Idowu, 2001). Traditionally, soybean is widely grown in the middle belt or the savannah zone of Nigeria (Okpara and
Ibiam, 2000) but, its production has presently expanded beyond the traditional production areas of the middle belt to cover other Northern and Southern parts of the country that were otherwise considered unsuitable or marginal for soybean production (Asiegbu and Okpara, 2002). However, there are highlighted constraints in the current attempts for the successful incorporation of the crop into the cropping system of these zones most of which are soil related constraints such as low $\mathrm{pH}$, nutrient deficiencies (phosphorus, potassium, molybdenum and sulphur), and toxic levels of some metals like aluminum, 
iron, and manganese (Rubaihayo et al., 2000). These factors have the potentials to reduce the yield of the crop (Singh et al., 1987; IITA, 1989). Some studies on the adaptability of soybean cultivars to the humid tropical conditions of the southeastern Nigeria have been carried out (Ikeorgu et al., 1990; Solomon and Uwah, 1996; Dada, 1998; Onyegbule, 1999, Okpara and Ibiam, 2000; Osodeke, 2001) and some varieties recommended.

Soybean responds both to P-fertilization and soil $\mathrm{P}$ level as well as soil location (Ogoke et al., 2003). Notable responses to phosphorus have been recorded from different ecological zones. Pal et al. (1989) observed that grain yield of soybean responded to $P$ fertilizer in 10 of 11 trials in northern Nigeria. Taiwari (1965), in the derived savanna zone of Nsukka (Southeastern Nigeria) obtained significant response of soybean to $20 \mathrm{~kg} \mathrm{~N}$ and $20 \mathrm{~kg}$ $\mathrm{P}_{2} \mathrm{O}_{5} /$ ha. Ochulor (1999) however, obtained no response due to the high level of phosphorus in the experimental site. Onuka and Ugbaja (1995), reported that the application of liming material (cement flue dust) at the rate of $1000 \mathrm{~kg} / \mathrm{ha}$ and phosphorus at the rate of $15 \mathrm{~kg}$ $\mathrm{P} / \mathrm{ha}$ increased the soil $\mathrm{pH}$ and grain yield of soybean in South-eastern Nigeria. Osodeke (2001) recorded a significant response to P-fertilizer application and recommended an application of $50 \mathrm{~kg} / \mathrm{ha} P$ depending on the soil available $P$.

Soybean yield has been characterized with high instability within and between species at different sites and among seasons (Radi et al., 1993; Moot and McNeil, 1995; Ma et al., 1998; Ambrose and Hedley, 1984) and the use of stable genotypes for high seed yield is an important objective for sustainable soybean production (Alghamdi, 1991; Carpenter and Board, 1997). The knowledge of the genetic variability in plant improvement programs and the adequate evaluation of breeding materials under different environments are very important (Comstock and Moll, 1963). Stable genotypes are less dependent upon good environments to perform well, and this makes their yield more predictable (Crossa, 1990; Dashiell et al., 1994; Baiyeri and Nwokocha, 2001). Beaver and Johnson (1981) noted that soybean breeders have traditionally emphasized wide adaptation rather than specific adaptation in their breeding programs and selected genotypes that perform well over a wide range of climatic conditions. Broad adaptation provides stability against the variability inherent in an ecosystem, but specific adaptations may provide a significant yield advantage in particular environments (Wade et al., 1999). Multi-environment testing makes it possible to identify cultivars that perform consistently from year to year (temporal variability) and those that perform consistently from location to location (spatial variability). Temporal stability is desired by and beneficial to growers, whereas spatial stability is beneficial to seed companies and breeders (Kang, 2002). Denis and Gower (1996) suggested that plant breeders should consider genotype $x$ environment interaction (GEI) to avoid missing varieties that, on average, perform poorly but do well when grown in specific environments or those that, on average, perform well but do poorly when grown in a particular environment.

The objective of the study was to determine the yields and yield components of five soybean genotypes, genotype $x$ environment interaction (GEI) and evaluate the stability of these genotypes in response to $\mathrm{P}$ fertilization.

\section{MATERIALS AND METHODS}

The experiment was conducted at the Michael Okpara University of Agriculture Teaching and Research Farm at Umudike (latitude $05^{\circ}$ $29^{\prime} \mathrm{N}$; longitude $07^{\circ} 33^{\prime} \mathrm{E}$; altitude $122 \mathrm{~m}$ ) in 2009 and 2010. In 2010 cropping seasons, an additional location, Amakama was added to study the effect of environmental variability. Amakama is located at latitude $05^{\circ} 28^{\prime} \mathrm{N}$, longitude $07^{\circ} 29^{\prime} \mathrm{E}$; altitude $154.25 \mathrm{~m}$. The soil is classified as sandy acidic soil and a pH of 4.55 . Umudike is in the humid tropics and has a total rainfall of about $2177 \mathrm{~mm}$ per annum, annual average temperature of about $26^{\circ} \mathrm{C}$. The soil has been classified as a sandy loam Ultisol (Agboola, 1979). The rainfall pattern is bimodal.

Two early and three medium maturing genotypes of soybean obtained from the germplasm of International Institute of Tropical Agriculture (IITA) were used (Table 1). The experiment was laid out as a split-plot in a randomized complete block design with the genotypes as main plot and the $P$ rates as the subplot in three replications. The $P$ rates of $0,10,20,30$ and $40 \mathrm{~kg} \mathrm{P}^{-1}$ as triple superphosphate (TSP, $20 \% \mathrm{P}$ ) were randomly allocated to subplots. The plot size in 2009 was $3 \mathrm{~m} \times 2 \mathrm{~m}$ plots with $50 \mathrm{~cm}$ furrow between the plots and $1 \mathrm{~m}^{2}$ between replications. In 2010, the plot size was $2 \mathrm{~m} \times 2 \mathrm{~m}$, with same spacing between plots and replications as in 2009 in both locations.

\section{Agronomic practices}

Planting was done on July 9, 2009 and July 30, 2010 in Umudike and on August 13, 2010 at Amakama. The land was ploughed and harrowed before planting seeds on flat. Seeds were sown at a plant spacing of $50 \mathrm{~cm} \times 10 \mathrm{~cm}$, inter and intra row spacing respectively $(200,000$ plants/ha). Two seeds were sown per stand and later thinned to one plant at three (3) weeks after planting (WAP). The different $P$ fertilizer dosages were drilled 1 WAP. Weed control was achieved by hoeing carried out twice at 3 and 6 WAP.

\section{Soil analysis}

Soil samples were obtained with a steel auger into a plastic bucket and properly mixed. It was air dried at room temperature and passed through $2 \mathrm{~mm}$ sieve before it was taken to the laboratory for analysis. The soil $\mathrm{pH}$ was measured in a soil/water ratio of 1:2 with glass electrode and $\mathrm{pH}$ meter (Maclean, 1965). Soil physical properties were determined by thee hydrometer (Juo, 1979). Total soil $\mathrm{N}$ was determined by the Kjeldahl method (Bremner, 1965), available $P$ by the Bray 1 method (Bray and Kurtz, 1945), exchangeable $\mathrm{K}$ by the use of a flame photometer.

\section{Data collection}

At physiological maturity, net plots were harvested for assessment $\left(0.9 \mathrm{~m}^{-2}\right)$. Data were collected on the seed yield $(\mathrm{kg} / \mathrm{ha})$, seed size (100 seed weight in grams), number of pods per plant and 
Table 1. Soybean genotypes and their maturity class.

\begin{tabular}{ll}
\hline Genotype & Maturity class \\
\hline TGX 1440-1E & Medium \\
TGX 1448-2E & Medium \\
TGX 1485-1D & Early \\
TGX 1835-10E & Early \\
TGX 1910-14F & Medium \\
\hline
\end{tabular}

Table 2. Soil physico-chemical properties of the study areas.

\begin{tabular}{lccc}
\hline \multirow{2}{*}{ Parameter } & \multicolumn{2}{c}{ UMUDIKE } & AMAKAMA \\
\cline { 2 - 4 } & $\mathbf{2 0 0 9}$ & $\mathbf{2 0 1 0}$ & $\mathbf{2 0 1 0}$ \\
\hline Texture & Sandy loam & Sandy loam & Sandy loam \\
Sand $(\%)$ & 66.4 & 79.20 & 75.20 \\
Silt $(\%)$ & 18.80 & 7.40 & 11.40 \\
Clay $(\%)$ & 14.80 & 13.40 & 13.40 \\
pH $\left(\mathrm{H}_{2} \mathrm{O}\right)$ & 5.06 & 5.04 & 4.89 \\
Phosphorus $(\mathrm{Mg} / \mathrm{kg})$ & 16.09 & 14.40 & 16.30 \\
Nitrogen $(\%)$ & 0.280 & 0.07 & 0.056 \\
Organic carbon $(\%)$ & 0.10 & 0.68 & 0.75 \\
Organic matter $(\%)$ & 0.17 & 1.17 & 1.30 \\
Calcium $\left(\mathrm{C} \mathrm{mol} \mathrm{kg}{ }^{-1}\right)$ & 3.60 & 3.20 & 2.40 \\
Magnesium $\left(\mathrm{C} \mathrm{mol} \mathrm{kg}^{-1}\right)$ & 2.00 & 2.00 & 1.20 \\
Potassium $\left(\mathrm{C} \mathrm{mol} \mathrm{kg}^{-1}\right)$ & 0.251 & 0.317 & 0.077 \\
Sodium $(\mathrm{C} \mathrm{mol} \mathrm{kg})$ & 0.113 & 0.244 & 0.270 \\
TEA $\left(\mathrm{C} \mathrm{mol} \mathrm{kg}{ }^{-1}\right)$ & 1.96 & 2.16 & 2.56 \\
ECEC $(\mathrm{C} \mathrm{mol} \mathrm{kg})$ & 7.924 & 7.921 & 6.507 \\
\hline
\end{tabular}

TEA, Total exchangeable anions; ECEC, effective cation exchange capacity.

number of seeds per plant.

\section{Statistical analysis}

Data collected were subjected to Analysis of Variance (ANOVA) using the mixed model procedures (PROCMIXED) in SAS (Little et al., 1996). The analysis estimated the genotype, phosphorus, year and location effects as well as their interactions. The stability pattern of the genotype $\times \mathrm{P}$ rates was examined across year and location using Genotype and Genotype-by-Environment interaction (GGE) biplot model (Yan, 2001).

\section{RESULTS AND DISCUSSION}

\section{Soil and weather characteristics of study area}

Table 2 shows the soil properties of the experimental sites. The results show that the soil texture is sandy loam. The soil $\mathrm{pH}$ ranged from 4.9 to 5.1 with the Amakama soil being more acidic than the Umudike soil. Soil phosphorus was high in Amakama but low at the Umudike in 2010. The soil nitrogen content was higher in Umudike than Amakama. Organic carbon was higher at Amakama than Umudike but Umudike had low ECEC and the basic cations - calcium, magnesium and potassium than Amakama-compared to the latter.

Figure 1 shows the monthly rainfall $(\mathrm{mm})$ distribution at Umudike. The average monthly rainfall was 177.16 and $194.16 \mathrm{~mm}$ in 2009 and 2010, respectively. The rainfall pattern showed a bimodal rainfall distribution in 2009 with peaks in April and September. Annual rainfall was higher in 2010 than in 2009 with no distinct break.

\section{Effect of genotype on soybean yield and yield parameters at different $\mathbf{P}$ fertilizer rates}

Soybean genotypes showed high variability in yield and yield associated traits. Genotype effect was highly significant $(P<0.01)$ on seed yield $(\mathrm{kg} / \mathrm{ha})$, seed size, number of pods/plant and number of seeds/plant in Umudike and Amakama (Tables 3 to 6). The genotypes TGX 1910-14F had the highest mean performance for seed yield and number of seeds/plant while TGX 1835$10 \mathrm{E}$ had the lowest mean values for seed yield, the 


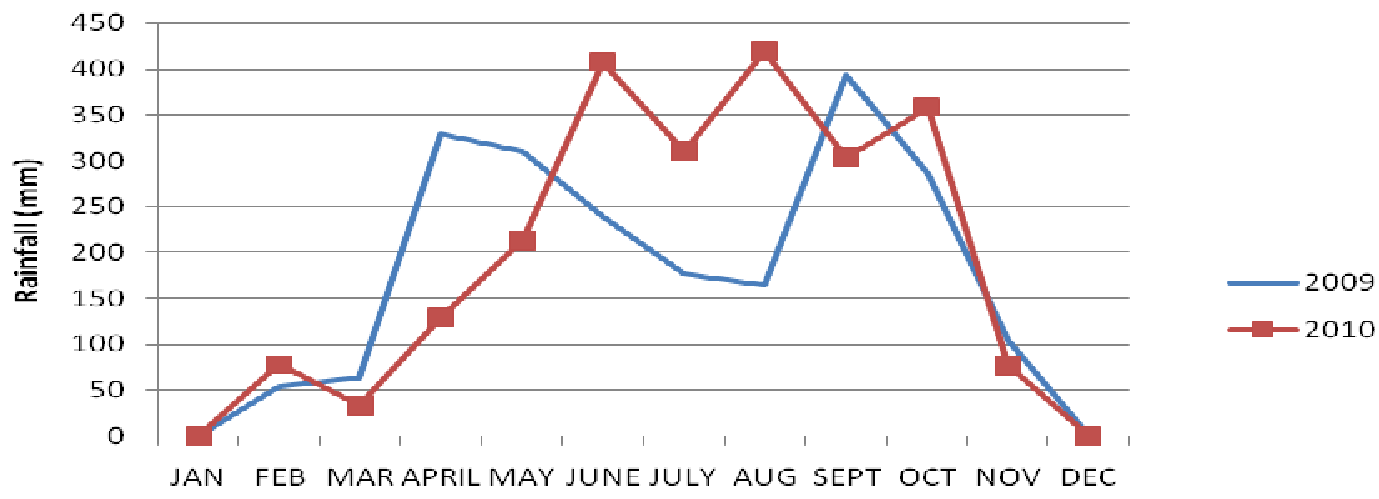

Month

Figure 1. Monthly rainfall (mm) distribution of Umudike in 2009 and 2010. Source: National Root Crops Research Institute's (NRCRI) Agro-meteorological Unit, Umudike.

Table 3. Effect of phosphorus rates and soybean genotypes, year, location and their interactions on seed yield (kg/ha).

\begin{tabular}{|c|c|c|c|c|c|}
\hline \multirow{3}{*}{ Treatment } & \multicolumn{5}{|c|}{ Location } \\
\hline & \multicolumn{3}{|c|}{ Umudike } & \multirow{2}{*}{$\begin{array}{c}\text { Amakama } \\
2010 \\
\end{array}$} & \multirow{2}{*}{${ }^{\#}$ Mean } \\
\hline & 2009 & 2010 & Mean & & \\
\hline \multicolumn{6}{|l|}{ Genotype } \\
\hline TGX1440-1E & 1407.05 & 861.76 & 1134.41 & 833.07 & 847.42 \\
\hline TGX1448-2E & 1518.68 & 866 & 1192.34 & 565.3 & 715.65 \\
\hline TGX1485-1D & 1435.06 & 568.87 & 1001.97 & 749.79 & 659.33 \\
\hline TGX1835-10E & 1128.35 & 461.25 & 794.8 & 597.01 & 529.13 \\
\hline TGX1910-14F & 1880.97 & 992.59 & 1436.78 & 843.32 & 917.96 \\
\hline \multicolumn{6}{|l|}{ P Rates (kg/ha) } \\
\hline 0 & 1507.83 & 604.55 & 1056.19 & 668.74 & 636.65 \\
\hline 10 & 1559.22 & 727.56 & 1143.39 & 860 & 793.78 \\
\hline 20 & 1339.19 & 781.94 & 1060.57 & 720.28 & 751.11 \\
\hline 30 & 1556.39 & 761.55 & 1158.97 & 645.89 & 703.72 \\
\hline 40 & 1407.48 & 874.88 & 1141.18 & 693.58 & 784.23 \\
\hline Mean & 1474.03 & 750.1 & 1112.07 & 717.7 & 733.9 \\
\hline LSD $_{0.05}$ & \multicolumn{3}{|c|}{$\begin{array}{l}\text { Genotype: } 154.35^{* * *} \text {; P-rates: ns; Genotype } \times \\
\text { P-rates: } 354.6^{\star * *} \text {; Year: } 97.62^{* \star} \text {; Year } \times \\
\text { Genotype: ns; Year } \times \text { P-rates: ns; Year } \times \\
\text { Genotype } \times \text { P-rates: } 838.7^{*}\end{array}$} & \multicolumn{2}{|c|}{$\begin{array}{l}\text { Genotype: } 130.32^{* * *} ; \text { P-rates: ns; } \\
\text { Genotype } \times \text { P-rates: } 313.6^{* *} ; \text { Location: } \\
\text { ns; Location } \times \text { Genotype: } 248.3^{* *} ; \\
\text { Location } \times \text { P-rates: ns; Location } x \\
\text { Genotype } \times \text { P-rates: ns }\end{array}$} \\
\hline
\end{tabular}

\#Mean: 2010 mean in Umudike and Amakama.

number of seeds/plant and number of pods/plant in both years and locations. Soybean seed size was smallest on TGX 1440-1E in both the year and location trials. TGX 1910-14F and TGX 1448-2E had the highest seed size and the number of pods/plant in year trials, while TGX 1485-1D and TGX 1440-1E gave the least seed size and the number of pods/plant in the location, respectively. The observed differential genotypic responses can be traceable to differences in inherent genetic composition and specific tolerance to $P$. Such responses had been recorded by Pulver et al. (1985), Nwoko and Sanginga (1999), Sanginga et al. (2000) and Osodeke (2001).

\section{Effect of Phosphorus rates on soybean yield and yield parameters}

$P$ at different rates significantly influenced only the number of pods/plant $(P<0.01)$ in year and number of seeds/plant $(P<0.05)$ in the location trials. However, the mean yield and yield components revealed a relative $P$ rate -trait responses. $P$ rates at $30 \mathrm{~kg} / \mathrm{ha}$ gave the highest seed yield in year but highest at $10 \mathrm{~kg} / \mathrm{ha}$ in location trial (Table 3). At $40 \mathrm{~kg} / \mathrm{ha} \mathrm{P}$, the highest mean number of pods/plant and the number of seeds/plant were obtained in the year and at $10 \mathrm{~kg} / \mathrm{ha} P$ in the location trial 
Table 4. Effect of Phosphorus rates and soybean genotypes, year, location and their interactions on seed size (g).

\begin{tabular}{|c|c|c|c|c|c|}
\hline \multirow{3}{*}{ Treatment } & \multicolumn{5}{|c|}{ Location } \\
\hline & \multicolumn{3}{|c|}{ Umudike } & \multirow{2}{*}{$\begin{array}{c}\text { Amakama } \\
2010 \\
\end{array}$} & \multirow{2}{*}{${ }^{\#}$ Mean } \\
\hline & 2009 & 2010 & Mean & & \\
\hline \multicolumn{6}{|l|}{ Genotype } \\
\hline TGX1440-1E & 8.95 & 9.73 & 9.34 & 11.27 & 10.5 \\
\hline TGX1448-2E & 8.92 & 10.6 & 9.76 & 10.47 & 10.54 \\
\hline TGX1485-1D & 8.83 & 11.47 & 10.15 & 11.6 & 11.54 \\
\hline TGX1835-10E & 9.66 & 10.13 & 9.9 & 11.53 & 10.83 \\
\hline TGX1910-14F & 9.68 & 11 & 10.34 & 11.53 & 11.27 \\
\hline \multicolumn{6}{|l|}{ P Rates (kg/ha) } \\
\hline 0 & 9.49 & 10.47 & 9.98 & 11.33 & 10.9 \\
\hline 10 & 9.35 & 10.47 & 9.91 & 11.27 & 10.87 \\
\hline 20 & 9.29 & 10.93 & 10.11 & 11.33 & 11.13 \\
\hline 30 & 9.52 & 10.4 & 9.96 & 11.2 & 10.8 \\
\hline 40 & 8.39 & 10.67 & 9.53 & 11.27 & 10.97 \\
\hline Mean & 9.21 & 10.59 & 9.9 & 11.28 & 10.94 \\
\hline LSD $_{0.05}$ & \multicolumn{3}{|c|}{$\begin{array}{l}\text { Genotype: } 0.52^{\star *} ; \text { P-rates: ns; Genotype } \times P \text { - } \\
\text { rates: ns; Year: } 0.33^{\star \star \star} ; \text { Year } \times \text { Genotype: } 0.89^{* *} \\
\text { Year } \times \text { P-rates: } 0.71^{*} ; \text { Year } \times \text { Genotype } \times \text { P-rates } \\
\text { ns }\end{array}$} & \multicolumn{2}{|c|}{$\begin{array}{l}\text { Genotype: } 0.422^{* * *} \text {; P-rates: ns; Genotype } \times \\
\text { P-rates: ns; Location: ns; Location × } \\
\text { Genotype: } 1.19^{* * *} \text { Location } \times \text { P-rates: ns; } \\
\text { Location } \times \text { Genotype } \times \text { P-rates: } 1.70^{*}\end{array}$} \\
\hline
\end{tabular}

"Mean: 2010 mean in Umudike and Amakama.

Table 5. Effect of phosphorus rates and soybean genotypes, year, location and their interactions on the number of pods per plant.

\begin{tabular}{|c|c|c|c|c|c|}
\hline \multirow{3}{*}{ Treatment } & \multicolumn{5}{|c|}{ Location } \\
\hline & \multicolumn{3}{|c|}{ Umudike } & Amakama & \multirow{2}{*}{${ }^{\#}$ Mean } \\
\hline & 2009 & 2010 & Mean & 2010 & \\
\hline \multicolumn{6}{|l|}{ Genotype } \\
\hline TGX1440-1E & 50.95 & 23.98 & 37.47 & 14.85 & 19.42 \\
\hline TGX1448-2E & 60.04 & 21.04 & 40.54 & 14.89 & 17.97 \\
\hline TGX1485-1D & 49.98 & 12.73 & 31.36 & 16.13 & 14.43 \\
\hline TGX1835-10E & 31.53 & 11.21 & 21.37 & 11.68 & 11.45 \\
\hline TGX1910-14F & 55.21 & 21.35 & 38.28 & 16.62 & 18.99 \\
\hline \multicolumn{6}{|l|}{ P Rates (kg/ha) } \\
\hline 0 & 46.69 & 14.48 & 30.72 & 15.34 & 14.91 \\
\hline 10 & 50.09 & 18.31 & 34.2 & 17.47 & 17.89 \\
\hline 20 & 44.69 & 19.11 & 31.9 & 14.83 & 16.97 \\
\hline 30 & 53.99 & 17.53 & 35.76 & 12.26 & 14.9 \\
\hline 40 & 51.98 & 20.89 & 36.44 & 14.28 & 17.59 \\
\hline Mean & 49.55 & 18.07 & 33.81 & 14.84 & 16.46 \\
\hline LSD $_{0.05}$ & \multicolumn{3}{|c|}{$\begin{array}{l}\text { Genotype: } 3.13^{* * *} \text {; P-rates: } 3.13^{\star *} \text {; Genotype } \times \\
\text { P-rates: } 7.60^{\star \star *} \text {; Year: } 1.99^{* * *} \text {; Year } \times \text { Genotype: } \\
6.47^{* * *} \text { Y Year } \times \text { P-rates: } 5.36^{\star} ; \text { Year } \times \text { Genotype } \times \\
\text { P-rates: } 12.41^{* * *}\end{array}$} & \multicolumn{2}{|c|}{$\begin{array}{l}\text { Genotype: } 2.89^{* * *} \text {; P-rates: ns; Genotype } \\
\times \quad \text { P-rates: } 7.70^{\star *} ; \text { Location: } 1.83^{\star * *} ; \\
\text { Location } \times \text { Genotype: } 5.64^{* * *} ; \text { Location } \times \\
\text { P-rates: ns; Location } \times \text { Genotype } \times \text { P- } \\
\text { rates: ns }\end{array}$} \\
\hline
\end{tabular}

"Mean: 2010 mean in Umudike and Amakama.

(Tables 5 and 6). Maximum soybean seed size was obtained at $20 \mathrm{~kg} / \mathrm{ha} P$ in both year and location trials (Table 4). At $0 \mathrm{~kg} / \mathrm{ha} \mathrm{P}$, seed yield (kg/ha) (Table 3) and number of seeds/plant (Table 6) in both years and locations were lowest. Number of pods/plant had the lowest mean performance at $0 \mathrm{~kg} / \mathrm{ha} \mathrm{P}$ in year and 
Table 6. Effect of phosphorus rates and soybean genotypes, year, location and their interactions on the number of seeds per plant.

\begin{tabular}{|c|c|c|c|c|c|}
\hline \multirow{3}{*}{ Treatment } & \multicolumn{5}{|c|}{ Location } \\
\hline & \multicolumn{3}{|c|}{ Umudike } & \multirow{2}{*}{$\begin{array}{c}\text { Amakama } \\
2010 \\
\end{array}$} & \multirow{2}{*}{ \#Mean } \\
\hline & 2009 & 2010 & Mean & & \\
\hline \multicolumn{6}{|l|}{ Genotype } \\
\hline TGX1440-1E & 78.79 & 43.69 & 61.24 & 36.78 & 40.24 \\
\hline TGX1448-2E & 84.85 & 40.4 & 62.63 & 27.48 & 33.94 \\
\hline TGX1485-1D & 82.35 & 25.19 & 53.77 & 32.6 & 28.9 \\
\hline TGX1835-10E & 58.12 & 22.64 & 40.38 & 25.99 & 24.32 \\
\hline TGX1910-14F & 95.85 & 45.06 & 70.46 & 35.5 & 40.28 \\
\hline \multicolumn{6}{|l|}{$P$ rates $(\mathrm{kg} / \mathrm{ha})$} \\
\hline 0 & 78 & 28.72 & 53.36 & 29.45 & 29.09 \\
\hline 10 & 83.48 & 34.64 & 59.06 & 38.47 & 36.56 \\
\hline 20 & 72.84 & 35.97 & 54.41 & 30.54 & 33.26 \\
\hline 30 & 81.05 & 36.64 & 58.85 & 28.93 & 32.79 \\
\hline 40 & 84.6 & 41.02 & 62.81 & 30.96 & 35.99 \\
\hline Mean & 80 & 35.4 & 57.7 & 31.67 & 33.54 \\
\hline LSD $_{0.05}$ & \multicolumn{3}{|c|}{ 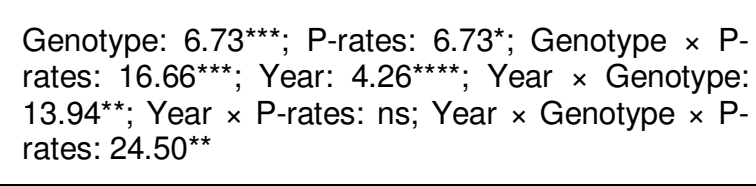 } & \multicolumn{2}{|c|}{$\begin{array}{l}\text { Genotype: } 5.42^{* * *} \text {; P-rates: ns; Genotyp€ } \\
\times \quad \text { P-rates: } 13.51^{* *} ; \quad \text { Location: } 3.43^{*} \\
\text { Location } \times \text { Genotype: } 10.66^{* * *} ; \text { Location } \\
\times \text { P-rates: ns; Location } \times \text { Genotype } \times \text { P. } \\
\text { rates: ns }\end{array}$} \\
\hline
\end{tabular}

\#Mean: 2010 mean in Umudike and Amakama.

$30 \mathrm{~kg} / \mathrm{ha}$ in location; seed size at $40 \mathrm{~kg} / \mathrm{ha} P$ in year trial and $30 \mathrm{~kg} / \mathrm{ha}$ in location. Significant $\mathrm{P}$ responses have also been reported by Ogoke et al. (2003) and Pal et al. (1989) in the northern Nigeria. In the south east agroecology, Osodeke (2001) recommended $50 \mathrm{~kg} / \mathrm{ha} \mathrm{P}$ for soybean production. The non response of traits to $\mathrm{P}$ rates might be obviously due to high level of phosphorus above the critical level of 8 to $12 \mathrm{ppm}$ recommended by Wade et al. (1999), Aune and Lal (1997), and Singh et al. (2000) for this agro ecology.

\section{Effect of year on soybean yield and yield parameters}

Significantly year effect $(P<0.001)$ was recorded for all the yield and yield components in this study. Number of pods/plant, number of seeds/plant and seed yield/ha were higher in 2009 than in 2010 (Tables 3, 5 and 6), while seed size had better performance in 2010 (Table 4) than in 2009. The variations in soybean yield and yield parameters as occasioned by year can be attributed to changes in both soil and weather environments across the years (Tenkouano and Baiyeri, 2007).

\section{Effect of location on soybean yield and yield parameters}

Location effect was significant $(P<0.5)$ on the number of pods/plant $(\mathrm{P}<0.001)$ and the number of seeds/plant but not seed yield and seed size. Mean performance of the measured attributes were higher at Umudike except for seed size which was higher at Amakama. Location effect had been attributed to differences in soil type and climatic factors as reported by Pulver et al. (1985) and Singh et al. (2000). It has also been reported that soybean perform differently across locations even within the same agro-ecology (Finlay and Wilkinson, 1963; Comstock and Moll, 1963; Saeed and Francis, 1983; Romagosa and Fox, 1993; Lin and Lin, 1994; Cooper et al., 1995; Baiyeri and Nwokocha, 2001; Moltaldo, 2001).

\section{Genotype $\times$ environment interactions (GEI) and yield components}

Some notable significant interactions existed in this study. Genotype X P rate interaction was highly significant $(\mathrm{P}<0.001)$ on yield, pods/plant and seeds/plant in year and location. Genotype $x$ year interaction was significant $(P<0.01)$ for all the other yield parameters except for seed yield/ha. Also, genotype $x$ location interaction was highly significant $(P<0.001)$ for all the attributes while $P$ rate $x$ year interaction was only significant $(P<0.5)$ on the number of pods/plant and seed size. Year $x$ genotype $x$ location interaction was significant for all the attributes except for seed size. These reported significant interaction effects confirm the presence of GEl and emphasis the need for the development of genotypes that are stable across diverse 


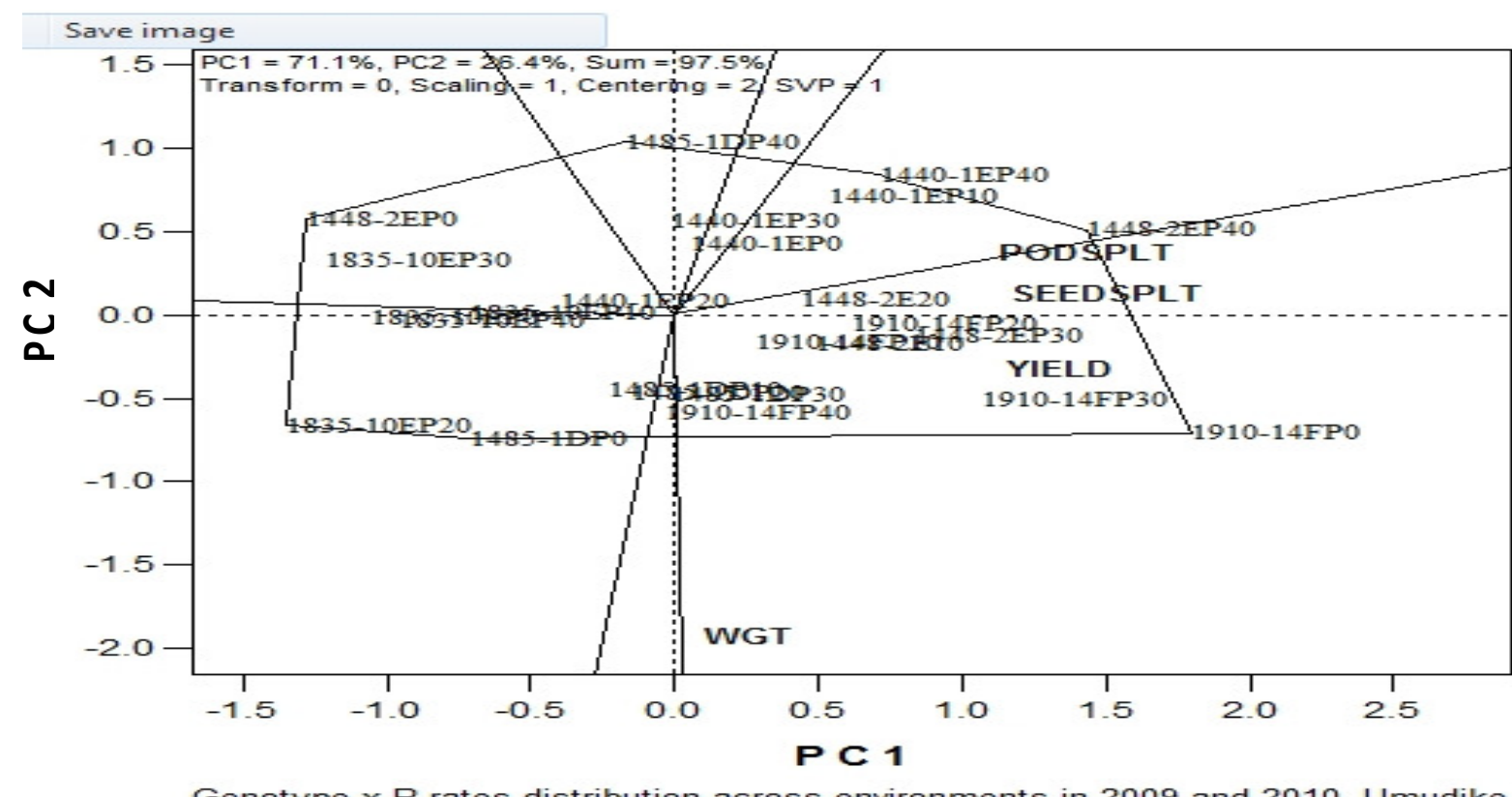

Figure 2. Genotype $\times \mathrm{P}$ rates distribution to soybean yield and yield components in 2009 and 2010, Umudike. Traits: Grain yield [YIELD], number of seeds/plant [SEEDSPLT], number of pods/plant [PODSPLT], seed size [WGT]; Genotype $\times$ P rate interaction: TGX $1440-1 \mathrm{E} \times 0 \mathrm{~kg} / \mathrm{ha}$ [1440-1EP0], TGX $1440-1 \mathrm{E} \times 10 \mathrm{~kg} / \mathrm{ha}$ [1440-1EP10], TGX $1440-1 \mathrm{E} \times 20 \mathrm{~kg} / \mathrm{ha}$ [1440-1EP20], TGX $1440-1 \mathrm{E} \times 30 \mathrm{~kg} / \mathrm{ha}$ [1440-1EP30], TGX $1440-1 \mathrm{E} \times 40 \mathrm{~kg} / \mathrm{ha}$ [1440-1EP40]; TGX 1448-2E $\times 0 \mathrm{~kg} / \mathrm{ha}$ [1448-2EP0], TGX 1448-2E $\times 10 \mathrm{~kg} / \mathrm{ha}$ [1448-2EP10], TGX 1448-2E $\times 20 \mathrm{~kg} / \mathrm{ha}$ [14482EP20], TGX 1448-2E $\times 30 \mathrm{~kg} / \mathrm{ha}$ [1448-2EP30], TGX 1448-2E $\times 40 \mathrm{~kg} / \mathrm{ha}$ [1448-2EP40]; TGX 1485-1D $\times 0 \mathrm{~kg} / \mathrm{ha}$ [1485-1DP0], TGX 1485-1D × $10 \mathrm{~kg} / \mathrm{ha}$ [1485-1DP10], TGX 1485-1D × $20 \mathrm{~kg} / \mathrm{ha}$ [1485-1DP20], TGX 1485-1D × 30 $\mathrm{kg} / \mathrm{ha}$ [1485-1DP30], TGX 1485-1D $\times 40 \mathrm{~kg} / \mathrm{ha}$ [1485-1DP40]; TGX 1910-14F $\times 0 \mathrm{~kg} / \mathrm{ha}$ [1910-14FP0], TGX 1910-14F $\times 10 \mathrm{~kg} / \mathrm{ha}$ [1910-14FP10], TGX 1910-14F × $20 \mathrm{~kg} / \mathrm{ha}$ [1910-14FP20], TGX 1910-14F × $30 \mathrm{~kg} / \mathrm{ha}$ [1910-14FP30], TGX $1910-14 \mathrm{~F} \times 40 \mathrm{~kg} / \mathrm{ha}[1910-14 \mathrm{FP} 40]$.

environments in the improvement of soybean. The implication of the high environmental influence will lead to low heritability and thus will render yield selection unpredictable (Ene-Obong and Okoye, 1992; Ariyo, 1995; Ofori, 1996). Similar interaction effects have been reported previously (Rao et al., 2002; Osodeke, 2001).

From Figures 2 and 3, major yield factors include number of pods/plant and number of seeds/plant. These traits therefore, can be selected for in the improvement of soybeans in the southeast agro-ecology. Similar associations have been reported in soybean and other grain legumes (Doku, 1970; Walton, 1971; Singh and Malhotra, 1973; Walson, 1987; Okoye and Ene-Obong, 1992; Okeleye et al., 1999; Osodeke, 2001).

\section{Genotype stability as influenced by $P$ rates}

The stability analysis (Figures 4 and 5 for Umudike and between Umudike and Amakama respectively) revealed that TGX 1910-14F and TGX 1440-1E genotypes had high mean performances but at different $P$ rates. TGX $1910-14 \mathrm{~F}$ at $0 \mathrm{~kg} / \mathrm{ha} P$ had the highest mean yield in the year trial but highly unstable. High mean yield and high stability performance however, was obtained at $30 \mathrm{~kg} / \mathrm{ha}$.
Across locations, TGX $1440-1 \mathrm{E}$ at $40 \mathrm{~kg} / \mathrm{ha}$ had the highest mean yield and high (Figure 5). This result tends to support specific than broad adaptation in stability studies and gave evidence for the existence of spatial and temporal variations. Specific adaptation, according to Evans (1993) has a greater significance to the subsistence farmers. Both types of spatial and temporal variations have also, been reported in Musa spp. (Baiyeri et al., 2000a, b, 2004). Spatial variations have been attributed to differences in climate (rainfall and temperature), soil quality (biophysical characteristics), and cultural practices. Changes over time cause the same factors to explain temporal variations (Tenkouano and Baiyeri, 2007).

In conclusion, the southeast agro ecology has high potential for soybean production with appreciable grain yield. Umudike showed a higher potential for soybean production than Amakama in this agro ecology. Major contributors of soybean grain yield are the number of pods/plant and number of seeds/plant. Genotype x environment interactions (GEI) played a significant role in this study. The genotypes TGX 1910-14F and TGX 1440$1 \mathrm{E}$ had high stable yield performance than the other genotypes but were not necessarily the highest performing genotypes. Genotypes showed differential 


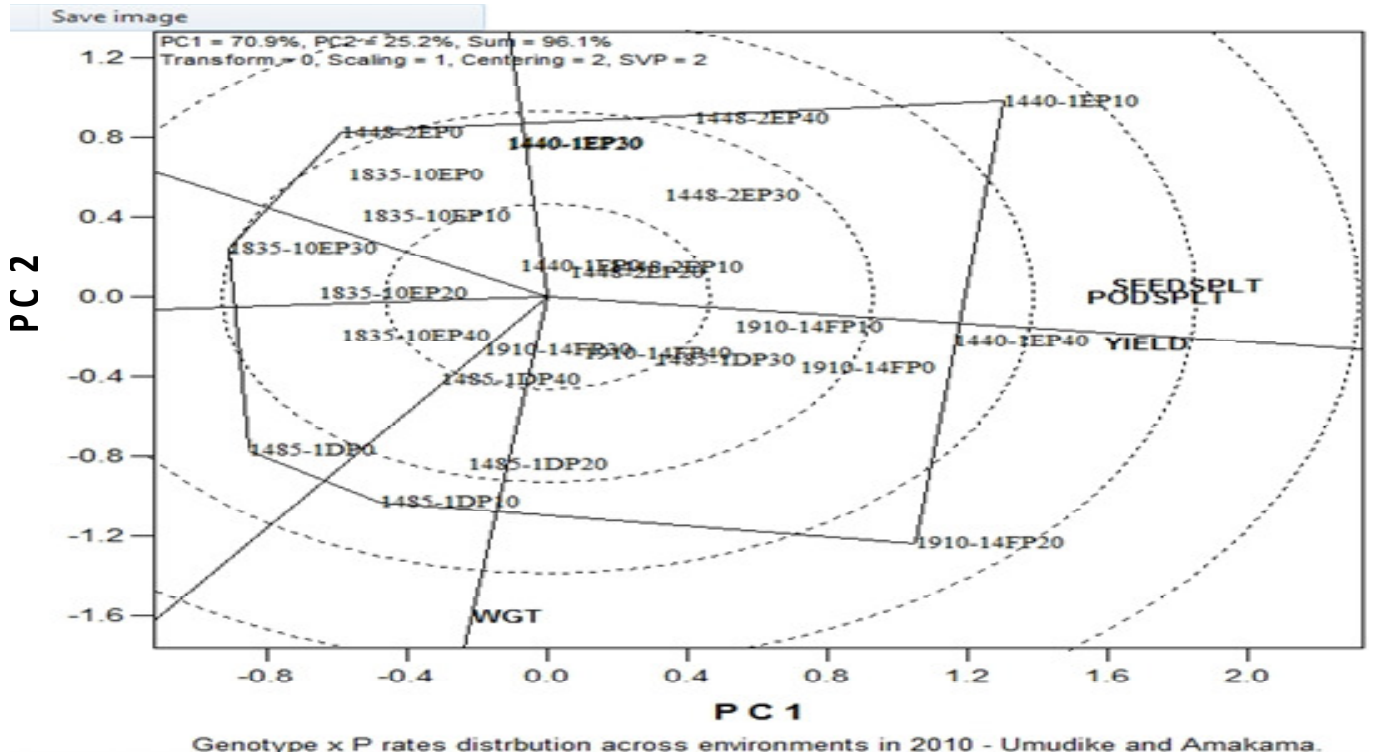

Figure 3. Genotype $\times \mathrm{P}$ rates distribution to soybean yield and yield components in 2010 between Umudike and Amakama. Traits: Grain yield [YIELD], number of seeds/plant [SEEDSPLT], number of pods/plant [PODSPLT], seed size [WGT]; Genotype $\times$ P rate interaction: TGX $1440-1 \mathrm{E} \times 0 \mathrm{~kg} / \mathrm{ha}$ [1440-1EP0], TGX 1440 -1E $\times 10 \mathrm{~kg} / \mathrm{ha}$ [1440-1EP10], TGX $1440-1 \mathrm{E} \times 20 \mathrm{~kg} / \mathrm{ha}$ [1440-1EP20], TGX $1440-1 \mathrm{E} \times 30 \mathrm{~kg} / \mathrm{ha}$ [1440-1EP30], TGX 1440 -1E $\times 40 \mathrm{~kg} / \mathrm{ha}$ [1440-1EP40]; TGX 1448-2E X 0kg/ha [1448-2EP0], TGX 1448-2E $\times 10 \mathrm{~kg} / \mathrm{ha}$ [1448-2EP10], TGX 1448-2E $\times 20 \mathrm{~kg} / \mathrm{ha}$ [1448-2EP20], TGX $1448-2 \mathrm{E} \times 30 \mathrm{~kg} / \mathrm{ha}$ [1448-2EP30], TGX 1448-2E $\times 40 \mathrm{~kg} / \mathrm{ha}$ [1448-2EP40]; TGX 1485-1D $\times 0 \mathrm{~kg} / \mathrm{ha}$ [1485-1DP0], TGX 1485-1D × $10 \mathrm{~kg} / \mathrm{ha}$ [1485-1DP10], TGX 1485-1D × $20 \mathrm{~kg} / \mathrm{ha}$ [1485-1DP20], TGX 1485-1D $\times 30 \mathrm{~kg} / \mathrm{ha}$ [1485-1DP30], TGX 1485-1D × $40 \mathrm{~kg} / \mathrm{ha}$ [1485-1DP40]; TGX 1910-14F $\times 0 \mathrm{~kg} / \mathrm{ha}$ [1910-14FP0], TGX 1910-14F × $10 \mathrm{~kg} / \mathrm{ha}$ [1910-14FP10], TGX 1910-14F $\times 20 \mathrm{~kg} / \mathrm{ha}$ [1910-14FP20], TGX 1910-14F × $30 \mathrm{~kg} / \mathrm{ha}$ [1910-14FP30], TGX 1910-14F $\times 40 \mathrm{~kg} / \mathrm{ha}$ [1910-14FP40].

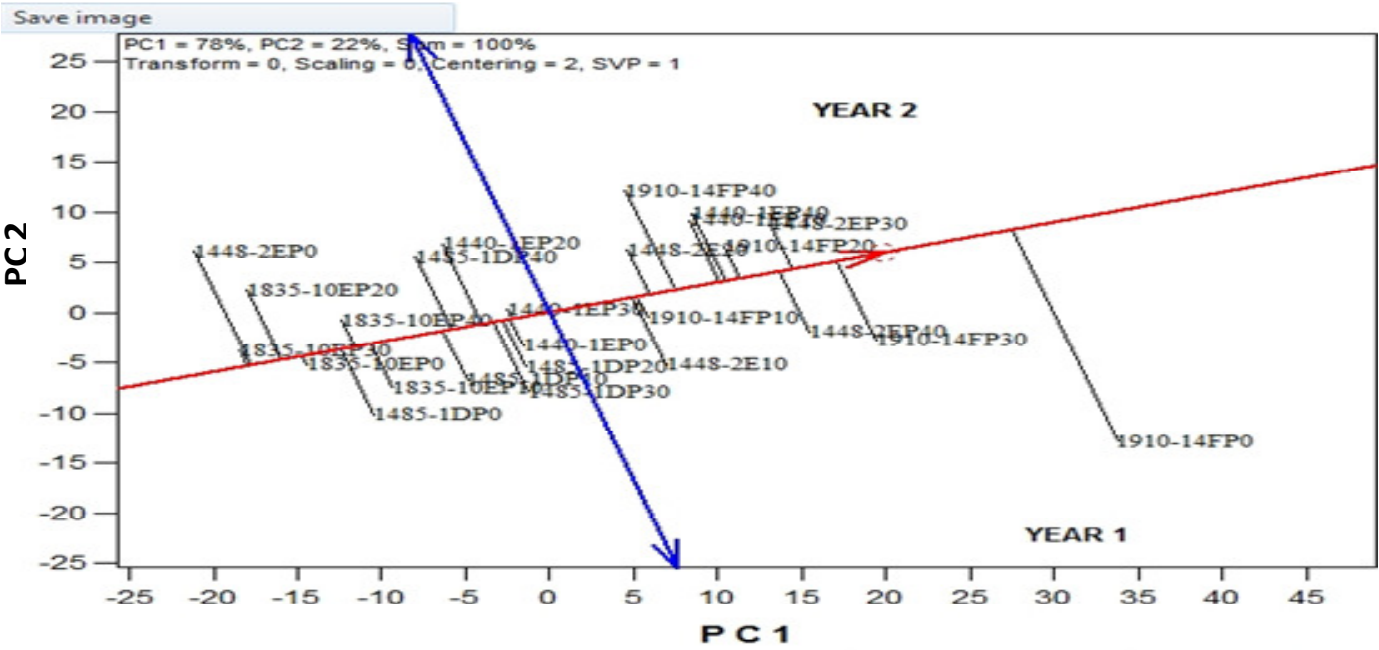

Mean vs stability Soybean yield $\mathrm{kg} / \mathrm{ha}$ of Genotype $\times \mathrm{P}$ rates in 2009 and 2010 . Umudike

Figure 4. Yield stability of Soybean genotypes $\times \mathrm{P}$ rates in 2009 and 2010 at Umudike. Year: 2009 [Year 1], 2010 [Year 2]; Genotype $\times$ P rate interaction: TGX $1440-1 \mathrm{E} \times 0 \mathrm{~kg} / \mathrm{ha}$ [1440-1EP0], TGX $1440-1 \mathrm{E} \times$ $10 \mathrm{~kg} / \mathrm{ha}$ [1440-1EP10], TGX $1440-1 \mathrm{E} \times 20 \mathrm{~kg} / \mathrm{ha}$ [1440-1EP20], TGX $1440-1 \mathrm{E} \times 30 \mathrm{~kg} / \mathrm{ha}$ [14401EP30], TGX 1440 -1E $\times 40$ kg/ha [1440-1EP40]; TGX 1448-2E $\times 0$ kg/ha [1448-2EP0], TGX 1448-2E $\times$ $10 \mathrm{~kg} / \mathrm{ha}$ [1448-2EP10], TGX 1448-2E $\times 20 \mathrm{~kg} / \mathrm{ha}$ [1448-2EP20], TGX 1448-2E $\times 30 \mathrm{~kg} / \mathrm{ha}$ [1448-2EP30], TGX 1448-2E $\times 40$ kg/ha [1448-2EP40]; TGX 1485-1D $\times 0$ kg/ha [1485-1DP0], TGX 1485-1D $\times 10 \mathrm{~kg} / \mathrm{ha}$ [1485-1DP10], TGX 1485-1D × $20 \mathrm{~kg} / \mathrm{ha}$ [1485-1DP20], TGX 1485-1D $\times 30 \mathrm{~kg} / \mathrm{ha}$ [1485-1DP30], TGX 1485-1D × $40 \mathrm{~kg} / \mathrm{ha}$ [1485-1DP40]; TGX 1910-14F $\times 0 \mathrm{~kg} / \mathrm{ha}$ [1910-14FP0], TGX 1910-14F $\times 10 \mathrm{~kg} / \mathrm{ha}$ [1910-14FP10], TGX 1910-14F × 20 kg/ha [1910-14FP20], TGX 1910-14F × 30 kg/ha [1910-14FP30], TGX 1910-14F $\times 40 \mathrm{~kg} / \mathrm{ha}$ [1910-14FP40]. 


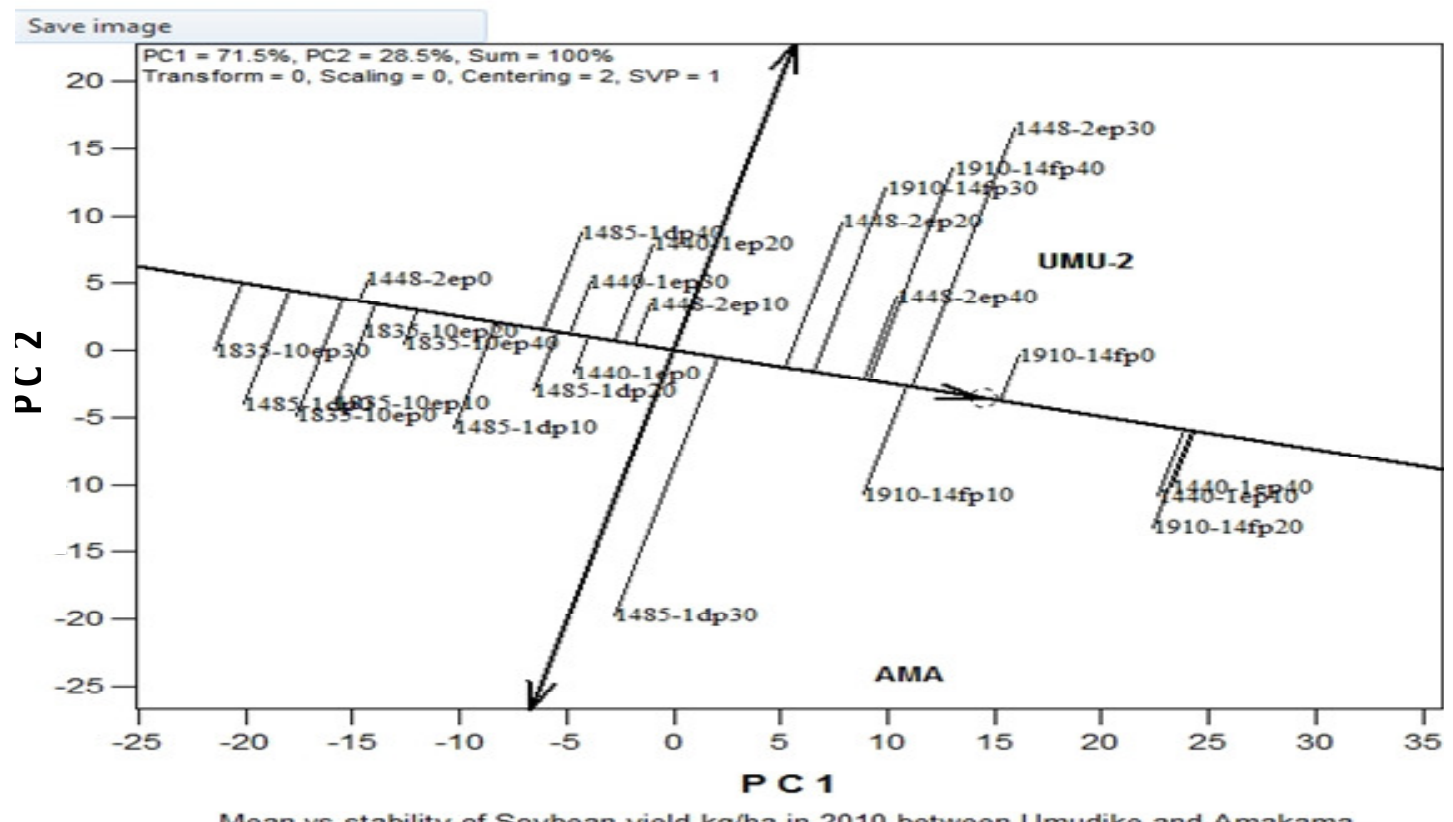

Figure 5. Yield stability of soybean genotypes $\times \mathrm{P}$ rates in 2010 between Umudike and Amakama. Locations: Amakama [AMA], Umudike [UMU-2]; Genotype $\times$ P rate interaction: TGX $1440-1 \mathrm{E} \times 0 \mathrm{~kg} / \mathrm{ha}$ [1440-1EP0], TGX $1440-1 \mathrm{E} \times 10 \mathrm{~kg} / \mathrm{ha}$ [1440-1EP10], TGX $1440-1 \mathrm{E} \times 20 \mathrm{~kg} / \mathrm{ha}[1440-1 \mathrm{EP} 20], \mathrm{TGX} 1440-1 \mathrm{E} \times 30 \mathrm{~kg} / \mathrm{ha}$ [1440-1EP30], TGX 1440 -1E $\times 40$ kg/ha [1440-1EP40]; TGX 1448-2E $\times 0$ kg/ha [1448-2EP0], TGX 1448-2E $\times 10 \mathrm{~kg} / \mathrm{ha}$ [1448-2EP10], TGX 1448-2E $\times 20 \mathrm{~kg} / \mathrm{ha}$ [1448-2EP20], TGX 1448-2E X 30kg/ha [1448-2EP30], TGX 1448-2E X 40kg/ha [1448-2EP40]; TGX 1485-1D $\times 0$ kg/ha [1485-1DP0], TGX 1485-1D $\times 10 \mathrm{~kg} / \mathrm{ha}$ [1485-1DP10], TGX 1485-1D × $20 \mathrm{~kg} / \mathrm{ha}$ [1485-1DP20], TGX 1485-1D × $30 \mathrm{~kg} / \mathrm{ha}$ [1485-1DP30], TGX 1485$1 \mathrm{D} \times 40 \mathrm{~kg} / \mathrm{ha}$ [1485-1DP40]; TGX 1910-14F $\times 0 \mathrm{~kg} / \mathrm{ha}$ [1910-14FP0], TGX 1910-14F $\times 10 \mathrm{~kg} / \mathrm{ha}$ [191014FP10], TGX 1910-14F × 20 kg/ha [1910-14FP20], TGX 1910-14F × 30 kg/ha [1910-14FP30], TGX 1910$14 \mathrm{~F} \times 40 \mathrm{~kg} / \mathrm{ha}[1910-14 \mathrm{FP} 40]$.

response to $P$ rate fertilization as well as other environmental factors used in this study and hence, supported narrow than broad stability. The two genotypes - TGX 1910-14F and TGX 1440-1E are therefore, recommended for improvement in the southeast agro ecology.

\section{REFERENCES}

Agboola SA (1979). An Agricultural Atlas of Nigeria. Oxford University Press, Great Britian. P. 153.

Alghamdi SS (1991). Effects of soybean planting dates and various cultivars of differing maturity groups on the incidence and severity of Sudden Death Syndrome. M.Sc. Thesis, Southern Illinois University, Carbondale, USA.

Alghamdi SS (2004). Yield stability of some soybean genotypes across diverse environments. Pak. J. Biol. Sci. 7(12):2109-2114.

Ambrose NJ, Hedley CL (1984). A population study to acid selection of improved dried pea (Pisum sativa) crop plants. Annals Bot. 53:665672.

Ariyo OJ (1995). Correlations and path-coefficient analysis of components of seed yield in soybeans. Afr. Crop Sci. J. 3(1):29-33

Asiegbu JE, Okpara DA (2002). Soybean Production in Marginal Soils of Southeastern Nigeria - Paper presented at $36^{\text {th }}$ Annual Conference of the Agricultural Society of Nigeria held at the Federal University of Technology, Owerri, Nigeria.

Aune JB, Lal R (1997). Agricultural productivity in the tropics and critical limits of properties of oxisols, ultisols, and alfisols. Tropical Agric.
(Trinidad). 74(2):96-103.

Baiyeri KP, Mbah BN, Tenkouano A (2000a). Yield components of triploid and tetraploid Musa varieties in Nigeria. Hort. Sci. 35(7):1338-1343.

Baiyeri KP, Nwokocha HN (2001). Evaluation of sweet potato genotypes for yield stability in southeastern Nigeria. J. Sustain. Agric. Environ. 3(2):254-262.

Baiyeri KP, Tenkouano A, Mbah BN, Mbagwu JSC (2000b). Ploidy and genomic group effects on yield components interaction in Bananas and Plantains across four environments in Nigeria. Sci. Hortic. 85:51-62.

Baiyeri KP, Tenkouano A, Mbah BN, Mbagwu JSC (2004). Phenological and yield evaluation of Musa genotypes under alley and sole cropping systems in southeastern Nigeria. Trop. Subtrop. Agroecosys. 4(3):137-144.

Beaver JS, Johnson RR (1981). Yield stability of determinate and indeterminate soybeans adopted to the Northern United States. Crop Sci. 21:449-453.

Bray RH, Kurtz LT (1945). Determination of total organic and available forms of phosphorus in soil. Soil Sci. 59:39-45.

Bremner JM (1965). Total nitrogen. In: Methods of soil analysis. Part 2. Chemical and Microbiological properties. C.A. Black (ed). American Soc. Agron. pp. 1149-1178.

Carpenter AC, Board JE (1997). Branch yield components controlling soybean yield stability across plant populations. Crop Sci. 37:885891.

Comstock RE, Moll RH (1963). Genotype-environment nteraction. In: Statistical genetics and plant breeding. Nat. Acad. Sci. 982:164-196.

Cooper M, Woodruff DR, Eisemann RC (1995). A selection strategy to accommodate genotype by environment interaction for grain yield of wheat managed-environment for selection among genotypes. Theor. 
Appl. Genet. 90:492-502.

Crossa J (1990). Statistical analyses of multilocation trials. Adv. Agron. 44:55-85.

Dada TO (1998). Effects of fertilizer, lime and organic manure on the nodulation and growth of soybean (Glycine max (L.) Merill) in south eastern Nigeria. B. Sc. Project Report. Federal University of Agriculture, Umudike, Nigeria.

Dashiell KE, Ariyo OJ, Bello L (1994). Genotype x environment interaction and simultaneous selection for high yield and stability in soybeans (Glycine max (L.) Merr.). Ann. Appl. Biol. 124:133-139.

Denis JB, Gower JC (1996). Asymptotic confidence regions for bioadditive models: interpreting genotype-environment interactions. Appl. Stat. 45:479-493.

Doku EV (1970). Effects of selfing and subsequent hybridization on the nodulation of cowpea (Vigna unguiculata (L.) Walp.), Ghana. J. Agric. Sci. 3:145-149.

Ene-Obong EE, Okoye FI (1992). Interrelationship between yield and ield components in the African yam bean, Sphenostylis sternocarpa (Hochst ex. A. Rich.) Harms. Beitr. Trop. Landwirt schaft. Vet. Med. 30(3):283-290.

Evans LT (1993). Crop evolution, adaptation and yield. Cambridge University Press, New York. P. 500.

Fekadu G, Hussein M, Getinet A (2009). Genotype x Environment interactions and stability of soybean for grain yield and nutrition quality. Afr. Crop. Sci. J. 17(2):87-99.

Finlay KW, Wilikison GN (1963). The analysis of adaptation in plant breeding programme. Aust. J. Agric. Res. 14:742-745.

IITA (1989). International Institute of Tropical Agriculture, Annual report, Ibadan, Nigeria. P. 129.

Ikeorgu JEG, lloka AW and Nwagbo EC (1990). Productivity and farmer acceptability of yam/maize/egusi for cowpea/soybean intercrop. Proceedings of the $5^{\text {th }}$ Annual Farming Systems Research and Extension Workshop in Southeastern Nigeria, Umudike, Nigeria.

Juo ASR (1979). Selected methods for soil and plant analysis. IITA. Manual series. P. 1.

Kang MS (2002). Genotype-Environment interaction: Progress and prospects. In: Kang MS (ed.) (2002). Quantitative genetics, genomics and plant breeding, CABI Publishing, Wallingford, U.K. pp. 221-243.

Lin CY, Lin CS (1994). Investigation of genotype-environment interaction by cluster analysis in animal experiments. Canadian J. Anim. Sci. 74:607-612.

Little RC, Milliken GA, Stroup WW, Wolfinger RD (1996). SAS System for mixed Modules. Statistical Analysis System Inc. Cary, NC, USA. p. 633.

Maclean EO (1965). Exchangeable aluminum. In: Black CA (ed). Methods of soil analysis. Plant II. Agron. 9:985-990.

Ma Q, Longnecker N, Emery N, Alkins C (1998). Growth and yield in Lupinus angustifolius are depressed byearly transient nitrogen deficiency. Aust. J. Agric. Res. 49:811-819.

Moltaldo HH (2001). Genotype by environment interactions in livestock breeding programs: A review. Interciencia 26(6):229-235

Moot DJ, McNeil DL (1995). Yield components, harvest index and plant type in relation to yield difference in field pea genotypes. Euphytica 86:31-40.

Nwoko H, Sanginga N (1999). Dependence of promiscuous soybean and herbaceous legumeson arbuscular mycorrhizal fungi and their response to Bradyrhizodial inoculation in low P. soil. Appl. Soil Ecol. $13: 251-258$

Ochulor UC (1999). Effect of phosphorus fertilizer nodulation and yield of soybean cultivars in acid soil of south eastern Nigeria. Department of crop and soil sciences, Federal University of Agriculture, Umudike.

Ofori I (1996). Correlation and path-coefficient analysis of components of seed yield in bambara groundnut (Vigna subterranean). Euphytica 91:103-107.

Ogoke IJ, Carsky RJ, Togun AO and Dashiell KE (2003). Maturity Class and $P$ Effects on Soybean grain yield in the moist savanna of West Africa. J. Agron. Sci. 189:422-427.

Okeleye K, Ariyo OJ, Olowe UI (1999). Evaluation of early and medium durationcowpea (Vigna unguiculata (L.) Walp.) Cultivars for agronomic traits and grain yield. Niger. Agric. J. 30:1-11.

Okoye FI, Ene-Obong EE (1992). Genetic variability and correlation studies in the African yambean-Sphenostylis stenocarp
(Hochst ex A. Rich.) Harms Nig. J. Bot. 5:75-83.

Okpara DA, Ibiam B (2000). Evaluation of Soybean varieties for adaptability to a bound tropical environment in Southeastern Nigeria. J. Sustain. Agric. Environ. 2: 26-31.

Onuka NA, Ugbaja RAE (1995). Response of soybean to liming and phosphorus Fertilizer in an acid utisol of South Eastern Nigeria. Trop. Oil Seeds J. 2:52-64.

Onyegbule U (1999). Evaluation of Nitrogen Fixing Capacity of some soybean cultivars in an Acid sandy soil. B. Sc. Project Report, Federal University of Agriculture, Umudike.

Osodeke VE (2001). Yield Performance, $\mathrm{N}_{2}$-fixation and fertilizer requirement of Soybean (Glycine max (Merril) L.) in some soils of the forest zone of southeastern Nigeria. A PhD Thesis- Department of soil science and Agro climatology, MOUAU.

Pal UR, Olufajo OO, Nnadi LA, Singh L (1989). Response of soybean (Glycine max (L.) Merr.) to phosphorus, potassium and molybdenum application. J. Agric. Sci. 112:131-136.

Pulver EL, Kueneman EA, Ranga R (1985). Identification of promiscuous nodulating soybean efficient in $\mathrm{N}_{2}$ Fixation. Crop Sci. 25:660-663.

Radi MM, El-Borai MA, Safia T, Abdalla AE, Sharaf and Desouki EF (1993). Estimates of stability parameters of yield of some soybean cultivars. J. Agric. Res. Tanta Univ. 11:86-91.

Rao MS, Mullinix BG, Rangappa M, Cebert E, Bhagsari AS, Sapra VT, Joshi JM, Dadson RB (2002). Genotype x Environment interactions and yield stability of food- grade soybean enotypes. Agron. J. 94:72-80.

Romagosa I, Fox PN (1993). Genotype x environment interaction and adaptation. In: Plant Breeding: Principles and Prospects. Hayward $\mathrm{MD}$, Bosemark NO and Romagosa I (eds.), Chapmam \& Hall, London. pp. 373-390.

Rubaihayo PR, Qualset CO, Visser GFR (2000). System wide review of plant breeding methodologies in the CGIAR, IITA sub-panel Report. pp. 10-11.

Saeed M, Francis CA (1983). Yield stability in relation to maturity in grain sorghum. Crop Sci. 23:683-689.

Sanginga N, Lyasse O, Singh BB (2000). Phosphorus use efficiency and nitrogen balance of cowpea breeding lines in a low $P$ soil of the derived savannah zone in West Africa. Plant Soil 220:119-128.

Singh SR, Rachie KO, Dashell KE (1987). Soybean for the Tropics: Research, Production and Utilization. John Wiley and Sons New York. P. 230.

Singh A, Carsky RJ, Lucas EO, Dashell K, Adeoye GO (2000). Soybean grain yield as affected by rainfall and soil properties in the Guinea Savannah of Nigeria. Niger. J. Soil Sci. 12:81-87.

Singh KB, Malhotra RS (1973). Yield components in Pigeon pea (Cajanus cajan (L.) Millsp). Madras Agric. J. 60:364-366.

Solomon MG, Uwah DF (1996). Varietal trials of soybean and their contribution to soil nitrogen. J. Appl. Chem. Agric Res. 3:25-31.

Taiwari G (1965). Effects of Nitrogen, Phosphorus and Potassium on flowering and yield of Soybean in Nigeria. Exp. Agric. J. 36:185-188.

Tenkouano A, Baiyeri KP (2007). Adaptation pattern and yield stability of banana and plantain genotypes grown in contrasting agro ecologies in Nigeria. Afr. Crop Sci. Conf. Proc. 8:337-384.

Wade LJ, McLaren CG, Quintana L, Harnpichitvitaya D, Rajatasereekul S, Sarwoto, Singh, AK, Rodriquez R, Sioongoo J, Sarkarung S (1999). Genotype by environment interactions across diverse rain fed lowland rice environments. Field Crops Res. 64:35-50.

Walson DR (1987). New approaches to understanding the growth and yield of pea crops. pp. 23-28. Inc. In: Jennyn WA, Wratti GS (Eds.) Peas: Management for quality. Agronomy Society for New Zealand special Publication. P. 6.

Walton PD (1971). The use of factor analysis in determining characters for yield selection in wheat. Euphytica 20:416-421.

Yan W (2001). GGEbiplot - a windows application for graphical analysis of multi-environment trial data and other types of two-way data Agron. J. 93(5), 1111-1118.

Yusuf IA, Idowu AA (2001). Evaluation of four soybean varieties for performance under different lime regimes on the acid soil of Uyo. Trop. Oil Seeds J. 6:65-70. 